\title{
Physical Development of Adolescents in the North
}

\author{
Lyudmila Marinova $^{1}$ and Nadezhda Savvina ${ }^{1, *}$
}

\author{
${ }^{1}$ North-Eastern Federal University named after M.K. Ammosov, Yakutsk, Russia \\ *Corresponding author. Email: nadvsavvina@mail.ru,kaf.ozizogib@mail.ru
}

\begin{abstract}
This article presents the research results of the physical development of 712 adolescents aged 15-16 years old and the updated regional standard for the physical development of adolescents in Yakutia. The body length and weight, the circumference of the chest, waist and thigh were measured. According to the results of the research, the average growth among indigenous boys was $168.4 \mathrm{~cm}(\mathrm{SD}=8.2)$, for girls $164.2 \mathrm{~cm}(\mathrm{SD}=8.0)$, the average body weight was $58.9 \mathrm{~kg}$ $(\mathrm{SD}=12.4), 56.5 \mathrm{~kg}(\mathrm{SD}=10.7)$, respectively. Average values of breast circumference in boys were $83.4 \mathrm{~cm}(\mathrm{SD}=8.4)$, in girls $83.5 \mathrm{~cm}(\mathrm{SD}=7.9)$, waist circumference $-71.7 \mathrm{~cm}(\mathrm{SD}=9.5)$ in boys, $70.0 \mathrm{~cm}(\mathrm{SD}=8.1)$ in girls, hip circumference were $91.0 \mathrm{~cm}(\mathrm{SD}=7.8)$ and $90.9 \mathrm{~cm}(\mathrm{SD}=7.0)$, respectively. A comparative analysis of somatometric indicators of modern adolescents with data from 2003 revealed that on average, modern 15 -year-old boys and girls became $5.8 \mathrm{~cm}$ higher than their peers. At the age of 16, young men did not show differences in growth, and modern girls of this age were $8.2 \mathrm{~cm}$ higher than their peers $(\mathrm{p}<0.000)$. Body weight in modern adolescents became higher in all age groups from an average of 2.6 to $9.8 \mathrm{~kg}(\mathrm{p}<0.000)$. The chest indices became larger on average from 2.1 to $5 \mathrm{~cm}(\mathrm{p}<0.000)$.
\end{abstract}

Keywords: physical development, adolescents, North

\section{INTRODUCTION}

A healthy younger generation is an essential condition for the prosperity and development of any society. In this regard, children and adolescents in Yakutia found themselves in the most difficult environmental, hygienic and socio-economic conditions. The peculiarity of the climate, such as a long period of low temperature, daily fluctuations in atmospheric pressure, polar night, solar radiation deficiency, magnetic anomalies, photoperiodism, nutrition affect the state of health of children and adolescents and their life expectancy in the future $[3,4,7]$.

Adolescence is the most vulnerable to health. A number of authors note that the most pronounced changes in physical and biological development are in this age $[3,5,7]$. One of the direct indicators of the health status of the younger generation is considered to be physical development, which has its own characteristics in each region of our country [3, 5]. Since physical development is an indicator of body growth and development, it is subject not only to biological laws, but to a greater extent depends on a complex set of social conditions that are crucial. The social environment in which a teenager grows change his health, including determining the level and dynamics of physical development. In Yakutia, for the first time, the physical development of the child population was studied by Professor Khanda M.V. and in 1988 regional standards were compiled and published. Subsequently, a number of researches were carried out for comparative analysis from 1995 to 1998 and from 2000 to 2004 . As a result of the study, some features in physical development in adolescents were obtained, such as: a decrease in body mass with an increase in length, which led to a decrease in the proportionality index a graceful body in adolescents of 10-14 years old; low body length by $4.6 \mathrm{~cm}$ and body weight by $5.3 \mathrm{~kg}$, and lag of secondary sexual signs development in girls compared to teenagers of the Russian Federation; predominance in the population of adolescents with a decrease in the muscle strength of the hands, as a result of a decrease in body weight not only due to the fat, but also the muscle component; lag behind the actual values of life capacity and the force of compression of the hands from the proper ones, which determines the low functionality in Yakut adolescents. Also compared to 1998 in 2003, the 
proportion of students with a body weight deficit increased by an average of $1 \%$, and almost doubled with excess body weight (from 4.5 to $8.4 \%$ in boys, from 3.8 to $7.7 \%$ in girls) $[3,4,7]$.

In order to compare the physical development of adolescents, we continued monitoring the physical development of adolescents from 2003 to 2016. Physical indicators of adolescents from 2016 living in the North (using the example of Yakutsk) were presented.

\section{MATERIALS AND METHODS}

We conducted a cross-sectional study in Yakutsk, which is the administrative center of the Republic of Sakha (Yakutia). Anthropometric examination and assessment of morphofunctional state of organism in 712 adolescents was performed. In order to assess physical development of adolescents, measurement of somatometric (height and body weight with accuracy up to $0.1 \mathrm{~kg}$ and $0.1 \mathrm{~cm}$ respectively, circumference of chest, waist and thigh with accuracy up to $0.1 \mathrm{~cm}$ and physiometric indices (muscular strength of hands, vital capacity of lungs) was carried out in accordance with the unified procedure. Waist and hip circumference measurements were carried out in accordance with WHO recommendations. All measurements were carried out in the morning in the equipped medical office of schools. The non-parametric (centile) method proposed in the early 30 s by C. Stuart and H.V. Meredith was used to develop individual physical development evaluation tables.

Calculation of samples was carried out with the use of Epi Info ${ }^{\mathrm{TM}}$, version 7.2.0.1. Taking into account the expected response at the level of $50 \%$, with an absolute error of no more than 5 at the $95 \%$ confidence level, 348 boys and 343 girls participated in the trial. The final sample was formed by 712 adolescents aged $15-16$ years old, of which 360 were girls, 352 were boys, which corresponds to the calculated data on the sample size based on the total teenage population of Yakutsk $[1,2,6]$.

Statistical analysis of the data was carried out using the SPSS statistical software package version, 22.0. The data was analyzed for compliance of the distribution of values of the studied characteristic with the law of normal distribution. Depending on the type of distribution, the mean value $(\mathrm{M})+$ standard deviation (SD) served as central trend and scattering measures. When comparing the average values, Student's t-test or Mann-Whitney criterion were used.

\section{RESEARCH RESULTS AND DISCUSSION}

The average growth among indigenous boys was $168.4 \mathrm{~cm}(\mathrm{SD}=8.2)$, for girls $164.2 \mathrm{~cm}(\mathrm{SD}=8.0)$, average body weight $58.9 \mathrm{~kg}(\mathrm{SD}=12.4), 56.5 \mathrm{~kg}$
$(\mathrm{SD}=10.7)$, respectively. Average values of chest circumference in boys were $83.4 \mathrm{~cm}(\mathrm{SD}=8.4)$, in girls $83.5 \mathrm{~cm}(\mathrm{SD}=7.9)$, waist circumference $-71.7 \mathrm{~cm}$ $(\mathrm{SD}=9.5)$ in boys, $70.0 \mathrm{~cm}(\mathrm{SD}=8.1)$ in girls, hip circumference were $91.0 \mathrm{~cm}(\mathrm{SD}=7.8)$ and $90.9 \mathrm{~cm}$ $(\mathrm{SD}=7.0)$, respectively.

A comparative analysis of physical development indicators by sex revealed high indicators in young men in height, body weight, waist circumference, which is generally characteristic of normal physical development relative to sexual dimorphism (Table 1). The growth rates of 15-16 year old boys are ahead of those of their peers $(p<0.05)$, which shows the development of the "second cross of growth curves," the so-called "pubertal growth" associated with the sexual development of young men. As you know, after 15 years, the growth rate of girls decreases, and by the age of 16 the final body sizes are formed. In young men, growth continues to 19 years, but already at a slow pace [5].

Table 1. Comparative analysis of mean values of somatometric indicators depending on sex

\begin{tabular}{|l|l|l|l|l|}
\hline \multirow{2}{*}{ Indicators } & \multicolumn{3}{|l|}{15 years old } & \multicolumn{2}{l|}{16 years old } \\
\cline { 2 - 5 } & Girls & Boys & Girls & Boys \\
\cline { 2 - 5 } & $\mathrm{N}=162$ & $\mathrm{~N}=163$ & $\mathrm{~N}=198$ & $\mathrm{~N}=189$ \\
\hline Height $(\mathrm{cm})$ & $162.4^{*}$ & $169.0^{*}$ & $165.6^{*}$ & $167.9^{*}$ \\
\hline Body weight $(\mathrm{cm})$ & $55.2^{*}$ & $60.1^{*}$ & 57.5 & 58.0 \\
\hline $\begin{array}{l}\text { Chest } \\
\text { circumference }(\mathrm{cm})\end{array}$ & 83.0 & 83.8 & 83.9 & 83.1 \\
\hline $\begin{array}{l}\text { Waist } \\
\text { circumference }(\mathrm{cm})\end{array}$ & $68.9^{*}$ & $72.8^{*}$ & 70.9 & 70.7 \\
\hline $\begin{array}{l}\text { Hip circumference } \\
(\mathrm{cm})\end{array}$ & 90.5 & 91.5 & 91.2 & 90.6 \\
\hline Note: $* \mathrm{p}<0,05$ & & & & \\
\hline
\end{tabular}

In order to determine the morphofunctional capabilities of adolescents, handgrip test was performed and vital lung capacity was measured (Table 2). The average values of dynamometry and VC indicators of modern adolescents correspond to the normal indicators approved in the methodological recommendations of the State Committee for Sanitary Supervision of the Russian Federation No. 01-19/31-17 of 17.03.1996.

For a more detailed study, we calculated the shares of adolescents with physiometric data below average, average and above average according to the indicators of the State Committee for Social Security of the Russian Federation No. 01-19/31-17 of 17.03.1996. The results of the research showed that modern boys show a decrease in muscle strength of the right hand ( $p<0.05)$, and in contrast an increase in muscle strength of the left hand $(\mathrm{p}<0.05)$. In modern girls, the growth of muscle strength of the hands of both hands was revealed $(p<0.05)$. VC study revealed low rates in half of modern adolescents ( $\mathrm{p}<0.05) .26 \%$ of boys and $17.5 \%$ of girls had normal VC indicators (Table 3 ). 
Table 2. Characteristics of dynamometry and VC indicators of adolescents by age and sex

\begin{tabular}{|c|c|c|c|c|c|c|c|c|c|c|c|c|c|c|}
\hline \multirow{3}{*}{ Age } & \multicolumn{7}{|l|}{ Boys } & \multicolumn{7}{|c|}{ Girls } \\
\hline & \multirow{2}{*}{$\mathrm{N}$} & \multicolumn{2}{|c|}{$\begin{array}{l}\text { Right hand } \\
\text { (kg) }\end{array}$} & \multicolumn{2}{|c|}{$\begin{array}{l}\text { Left hand } \\
\text { (kg) }\end{array}$} & \multicolumn{2}{|c|}{ VC (I) } & \multirow[t]{2}{*}{$\mathrm{N}$} & \multicolumn{2}{|c|}{$\begin{array}{l}\text { Right hand } \\
\text { (kg) }\end{array}$} & \multicolumn{2}{|c|}{$\begin{array}{l}\text { Left hand } \\
(\mathrm{kg})\end{array}$} & \multicolumn{2}{|c|}{ VC (I) } \\
\hline & & $M$ & $\mathrm{SD}$ & $M$ & $\mathrm{SD}$ & $M$ & SD & & $M$ & SD & $M$ & $\mathrm{SD}$ & M & SD \\
\hline 15 & 163 & 29.9 & 9.9 & 29.3 & 9.9 & 2.4 & 1.1 & 162 & 23.6 & 6.7 & 22.3 & 6.5 & 2.2 & 1.0 \\
\hline 16 & 189 & 28.9 & 10.0 & 27.1 & 9.8 & 2.4 & 1.0 & 198 & 26.9 & 9.4 & 25.7 & 9.7 & 2.3 & 0.9 \\
\hline
\end{tabular}

Table 3. Characteristics of morphofunctional capabilities of adolescents according to the indicators of GOST Russia of 17.03.1996

\begin{tabular}{|c|c|c|c|c|c|c|}
\hline \multirow[t]{2}{*}{ Indicators } & \multicolumn{2}{|c|}{$\begin{array}{l}\text { Below } \\
\text { average }\end{array}$} & \multicolumn{2}{|c|}{ Average } & \multicolumn{2}{|c|}{$\begin{array}{l}\text { Above } \\
\text { average }\end{array}$} \\
\hline & $\sqrt{N}$ & $\%$ & $N$ & $\%$ & $\sqrt{N}$ & $\%$ \\
\hline \multicolumn{7}{|l|}{ Boys } \\
\hline $\begin{array}{l}\text { Muscle strength of } \\
\text { the right hand }\end{array}$ & 135 & $38.4^{*}$ & 95 & 27.0 & 122 & 34.7 \\
\hline $\begin{array}{l}\text { Left hand muscle } \\
\text { strength }\end{array}$ & 107 & 30.4 & 119 & 33.8 & 126 & $35.8^{*}$ \\
\hline VC & 182 & $53.8^{*}$ & 88 & 26.0 & 68 & 20.1 \\
\hline \multicolumn{7}{|l|}{ Girls } \\
\hline $\begin{array}{l}\text { Muscle strength of } \\
\text { the right hand }\end{array}$ & 67 & 18.6 & 138 & 38.3 & 155 & $43.1^{*}$ \\
\hline $\begin{array}{l}\text { Left hand muscle } \\
\text { strength }\end{array}$ & 51 & 14.2 & 96 & 26.7 & 213 & $59.2^{*}$ \\
\hline VC & 172 & $50.3^{*}$ & 60 & 17.5 & 110 & 32.2 \\
\hline
\end{tabular}

In order to monitor the physical development of adolescents, we conducted a comparative analysis of the somatometric and physiometric data obtained in 2003 and 2016. The results show an increase in somatometric indicators in modern adolescents, in addition to the height and circumference of the chest at the age of 16 in young men, these indicators are maintained at the same level (Table 4).

On average, modern 15-year-old boys and girls became $5.8 \mathrm{~cm}$ higher than their peers. At the age of 16 , young men did not show differences in growth, and modern girls of this age were $8.2 \mathrm{~cm}$ higher than their peers. Body weight in modern adolescents became higher in all age groups from an average of 2.6 to 9.8 $\mathrm{kg}$. The chest indices became larger and averaged from 2.1 to $5 \mathrm{~cm}$.

Features in the morphofunctional capabilities of modern adolescents have also been identified. In modern boys aged 16, a decrease in muscle strength of the left $(\mathrm{p}<0.000)$ and right hand $(\mathrm{p}<0.000)$ was noted. In modern girls, on the contrary, the dynamometry of both hands was higher $(\mathrm{p}<0.000)$ compared with data from 2003 in both age groups (Table 5).

Table 4. Comparative characteristics of somatometric indicators of

\begin{tabular}{|c|c|c|c|c|c|c|c|c|c|c|}
\hline \multirow{2}{*}{$\begin{array}{l}\text { 15-16 years old adolescents in the } \\
\text { Republic of Sakha (Yakutia) in } 2003 \\
\text { and 2016.Age }\end{array}$} & \multicolumn{5}{|c|}{ Boys } & \multicolumn{5}{|c|}{ Girls } \\
\hline & N & 2016 & N & 2003 & p & N & 2016 & N & 2003 & p \\
\hline \multicolumn{11}{|l|}{ Height $(\mathrm{cm})$} \\
\hline 15 & 145 & $168.4 \pm 8.1$ & 139 & $162.6 \pm 8.7$ & 0.000 & 145 & $162.6 \pm 7.0$ & 160 & $156.8 \pm 8.6$ & 0.000 \\
\hline 16 & 201 & $168.3 \pm 8.3$ & 156 & $167.7 \pm 7.2$ & 0.473 & 201 & $165.2 \pm 8.5$ & 177 & $157.6 \pm 5.7$ & 0.000 \\
\hline \multicolumn{11}{|l|}{ Body mass $(\mathrm{kg})$} \\
\hline 15 & 145 & $60.1 \pm 12.2$ & 139 & $50.3 \pm 9.0$ & 0.000 & 145 & $55.2 \pm 9.63$ & 160 & $49.6 \pm 8.3$ & 0.000 \\
\hline 16 & 201 & $58.0 \pm 12.6$ & 156 & $55.4 \pm 8.9$ & 0.029 & 201 & $57.5 \pm 11.3$ & 177 & $50.3 \pm 8.0$ & 0.000 \\
\hline \multicolumn{11}{|l|}{ Chest circumference $(\mathrm{cm})$} \\
\hline 15 & 145 & $84.3 \pm 8.3$ & 139 & $79.3 \pm 7.1$ & 0.000 & 145 & $83.0 \pm 7.8$ & 160 & $80.9 \pm 7.5$ & 0.017 \\
\hline 16 & 201 & $82.9 \pm 8.5$ & 156 & $83.6 \pm 7.4$ & 0.415 & 201 & $84.0 \pm 7.9$ & 177 & $81.5 \pm 6.9$ & 0.001 \\
\hline
\end{tabular}

Based on our research, we proposed centile tables of growth, body weight, chest circumference, waist and hip circumference for modern teenagers of 15 and 16 years old of the indigenous population of Yakutia (Table 6). 
Table 5. Comparative characteristics of physiometric parameters of 15-16 years old adolescents in the Republic of Sakha (Yakutia) in 2003 and 2016

\begin{tabular}{|c|c|c|c|c|c|c|c|c|c|c|}
\hline \multirow{2}{*}{ Age } & \multicolumn{6}{|c|}{ Left hand muscle strength } & \multicolumn{4}{|c|}{ Right hand muscle strength } \\
\hline & $\mathrm{N}$ & 2016 & & $\mathrm{~N}$ & 2016 & & $\mathrm{~N}$ & 2016 & & $\mathrm{~N}$ \\
\hline \multicolumn{11}{|c|}{ Boys } \\
\hline 15 & 145 & $29.2 \pm 10.1$ & 15 & 145 & $29.2 \pm 10.1$ & 15 & 145 & $29.2 \pm 10.1$ & 15 & 145 \\
\hline 16 & 201 & $27.1 \pm 9.6$ & 16 & 201 & $27.1 \pm 9.6$ & 16 & 201 & $27.1 \pm 9.6$ & 16 & 201 \\
\hline \multicolumn{11}{|c|}{ Girls } \\
\hline 15 & 144 & $22.3 \pm 6.7$ & 15 & 144 & $22.3 \pm 6.7$ & 15 & 144 & $22.3 \pm 6.7$ & 15 & 144 \\
\hline 16 & 212 & $25.5 \pm 9.0$ & 16 & 212 & $25.5 \pm 9.0$ & 16 & 212 & $25.5 \pm 9.0$ & 16 & 212 \\
\hline
\end{tabular}

Table 6. Somatometric indicators of boys and girls in Yakutsk

\begin{tabular}{|c|c|c|c|c|c|c|c|c|c|c|c|c|}
\hline \multirow{2}{*}{$\begin{array}{l}\text { Age } \\
\text { years }\end{array}$} & \multirow{2}{*}{ N } & \multirow{2}{*}{ M } & \multirow{2}{*}{ SD } & \multirow{2}{*}{ Min. } & \multirow{2}{*}{ Max. } & \multicolumn{7}{|c|}{ Centile interval ( \%) } \\
\hline & & & & & & $3 \%$ & $10 \%$ & $25 \%$ & $50 \%$ & $75 \%$ & $90 \%$ & $97 \%$ \\
\hline \multicolumn{13}{|c|}{ Boys } \\
\hline \multicolumn{13}{|c|}{ Body length (cm) } \\
\hline 15 & 163 & 169.0 & 8.4 & 148.4 & 193.0 & 151.8 & 158.0 & 163.8 & 170.0 & 175.0 & 178.0 & 186.0 \\
\hline 16 & 189 & 167.9 & 8.1 & 150.5 & 187.0 & 154.0 & 156.0 & 162.0 & 168.0 & 173.0 & 179.0 & 183.0 \\
\hline \multicolumn{13}{|c|}{ Body weight (kg) } \\
\hline 15 & 163 & 60.1 & 12.0 & 37.2 & 100.0 & 41.5 & 48.0 & 51.7 & 57.8 & 66.1 & 75.6 & 88.4 \\
\hline 16 & 189 & 58.0 & 12.7 & 39.0 & 105.0 & 42.0 & 45.2 & 50.0 & 55.0 & 62.2 & 71.5 & 97.6 \\
\hline \multicolumn{13}{|c|}{ Chest circumference $(\mathrm{cm})$} \\
\hline 15 & 163 & 83.7 & 8.1 & 68.5 & 113.0 & 72.0 & 74.0 & 78.0 & 82.0 & 88.0 & 96.0 & 101.0 \\
\hline 16 & 189 & 83.1 & 8.6 & 63.0 & 124.0 & 71.0 & 74.0 & 77.0 & 82.0 & 87.0 & 93.0 & 104.0 \\
\hline \multicolumn{13}{|c|}{ Waist circumference $(\mathrm{cm})$} \\
\hline 15 & 163 & 72.8 & 8.9 & 57.0 & 109.0 & 60.0 & 63.0 & 67.0 & 71.0 & 77.0 & 85.0 & 96.0 \\
\hline 16 & 189 & 70.7 & 10.0 & 55.0 & 118.0 & 57.0 & 61.0 & 65.0 & 69.0 & 74.0 & 82.0 & 98.0 \\
\hline \multicolumn{13}{|c|}{ Hip circumference $(\mathrm{cm})$} \\
\hline 15 & 163 & 91.5 & 7.7 & 75.0 & 117.0 & 78.0 & 84.0 & 87.0 & 90.0 & 96.0 & 102.0 & 108.0 \\
\hline 16 & 189 & 90.6 & 7.9 & 51.0 & 120.0 & 80.0 & 83.0 & 86.0 & 90.0 & 93.0 & 100.0 & 112.0 \\
\hline \multirow{2}{*}{\multicolumn{13}{|c|}{$\begin{array}{l}\text { Girls } \\
\text { Body length }(\mathrm{cm})\end{array}$}} \\
\hline & \multicolumn{12}{|c|}{ Body length $(\mathrm{cm})$} \\
\hline 15 & 162 & 162.4 & 6.9 & 146.0 & 182.0 & 150.0 & 155.0 & 158.0 & 162.0 & 166.0 & 173.0 & 177.2 \\
\hline 16 & 198 & 165.6 & 8.5 & 134.5 & 189.0 & 152.0 & 155.0 & 159.2 & 165.0 & 172.0 & 178.0 & 181.5 \\
\hline \multicolumn{13}{|c|}{ Body weight (kg) } \\
\hline 15 & 162 & 55.2 & 9.9 & 38.2 & 86.0 & 39.9 & 44.6 & 47.3 & 53.5 & 60.0 & 67.6 & 79.0 \\
\hline 16 & 198 & 57.5 & 11.2 & 38.5 & 111.8 & 42.0 & 46.0 & 50.0 & 55.2 & 63.0 & 71.1 & 84.5 \\
\hline \multicolumn{13}{|c|}{ Chest circumference $(\mathrm{cm})$} \\
\hline 15 & 162 & 83.0 & 8.1 & 58.0 & 103.0 & 70.0 & 74.0 & 77.0 & 82.0 & 87.0 & 95.0 & 100.0 \\
\hline 16 & 198 & 83.9 & 7.7 & 68.0 & 112.0 & 72.0 & 75.0 & 79.0 & 83.0 & 88.0 & 93.0 & 102.0 \\
\hline \multicolumn{13}{|c|}{ Waist circumference $(\mathrm{cm})$} \\
\hline 15 & 162 & 68.9 & 7.7 & 40.0 & 94.0 & 59.0 & 60.0 & 63.0 & 68.0 & 73.0 & 79.0 & 87.0 \\
\hline 16 & 198 & 70.9 & 8.3 & 51.0 & 100.0 & 57.0 & 62.0 & 66.0 & 69.5 & 75.0 & 83.0 & 90.0 \\
\hline \multicolumn{13}{|c|}{ Hip circumference $(\mathrm{cm})$} \\
\hline 15 & 162 & 90.5 & 6.9 & 77.0 & 111.0 & 80.0 & 83.0 & 85.0 & 90.0 & 95.0 & 100.0 & 107.0 \\
\hline 16 & 198 & 91.2 & 7.1 & 78.0 & 115.0 & 80.0 & 84.0 & 86.0 & 90.5 & 94.5 & 100.0 & 109.0 \\
\hline
\end{tabular}

\section{CONCLUSION}

According to the results of comparing anthropometric indicators with a difference of more than ten years, modern adolescents revealed an excess of average indicators of growth and body weight. Teenagers have become taller and larger in body weight. Chest circumference increased. According to the results of the assessment of physiometric indicators, modern boys of 16 years old have a decrease in morphofunctional capabilities in the form of muscle strength of both hands $(\mathrm{p}<0.000)$, in girls this indicator has become higher in both age groups $(p<0.000)$.

Some authors note a slowdown in acceleration processes as a result of the impact of adverse socioeconomic and environmental facts. On the contrary, our results show that modern adolescents have become larger, while young men are physically weaker. 


\section{REFERENCES}

[1] A.M. Grzybowski, Confidence Intervals for Frequencies and Beats, Hum. Ecol. 5 (2008) 57-60.

[2] A.M. Grzybowski, Analysis of nominal data (independent observations), Hum. Ecol. 6 (2008) 58-68.

[3] V. Chasnyk, T. Burtseva, M. Savvina et al., Once more about customized versus population-based growth charts: how to assess physical development of the indigenous children of the north? ADC, 104(Suppl 3) (2019) A62.

[4] V.B. Egorova, N.V. Savvina, S.Yu. Artamonova, N.A. Sleptsova, The state of health of adolescents in the Republic of Sakha (Yakutia), Yakutsk Med. J. 3/51 (2015) 33-36.

[5] V.R. Kuchma, N.A. Skoblina, Informative value of assessing the physical development of children and adolescents in population studies, Quest. of modern pediat. 7/1 (2008) 26-28.

[6] K.K. Kholmatova, M.A. Gorbatova, O.A. Kharkova, A.M. Grzybowski, Cross-sectional Survey: Planning, Sample Size, Data Analysis, Hum. Ecol. 2 (2016) 49-56.

[7] L.G. Marinova, N.V. Savvina, I.L. Savvina, Adolescent: Growth and Development in the Northm Yakutsk Med. J. 2(54) (2016) 29-32. 